\title{
A new transgenic mouse model for studying the neurotoxicity of spermine oxidase dosage in the response to excitotoxic injury
}

\author{
Emanuela Angelucci ${ }^{1 *}$, Sandra Moreno ${ }^{1}$, Marcello D'Amelio ${ }^{2}$, Roberta Nardacci ${ }^{3}$, Francesco Cecconi ${ }^{2}$, \\ Paolo Mariottini ${ }^{1}$, Manuela Cervelli ${ }^{1}$ \\ From Molecular Neurodegeneration: Basic biology and disease pathways \\ Cannes, France. 10-12 September 2013
}

\section{Background}

A recently generated mouse genetic model overexpressing SMO provides novel evidences of the complex and critical functions carried out by SMO and Spm in mammalian brain [1]. Spermine has been demonstrated to be the strongest PA modulator of some Glu receptors [2,3].

\section{Materials and methods}

A mouse line was engineered with the aim to investigate the effects of SMO overexpression in brain, up to now unexplored [4]. A Cre/loxP-based genetic model was constructed to obtain SMO overexpressing transgenic animals conditionally. The mouse founder line (JoSMO), ubiquitously expressing GFP, was bred with a transgenic line expressing the Cre recombinase in the brain neocortex. Double transgenic mice (JoSMOrec) were obtained to specifically overexpress SMO in a tissue specific way.

\section{Results}

JoSMOrec mice showed a significant astroglial and microglial activation in the neocortex, showing a more pronounced brain damage during ageing. In excitotoxic condition, KA injected JoSMOrec mice resulted more sensitive than control animals, showing more severe behavioural phenotype, astrogliosis and microgliosis in the neocortex and also a higher number of neurons with abnormal morphological features, all evident markers of brain injury. In SMO overexpressing mice it has been observed a different Spm/Spd ratio that could affect GluRs, producing changes in $\mathrm{Ca}^{2+}$ flux through

"University of "Roma Tre", Rome, Italy

Full list of author information is available at the end of the article
GluRs and being responsible for the higher sensitivity to KA treatment [4].

\section{Conclusions}

These results indicate an important role of SMO during excitotoxicity and neuronal damages, providing new perspectives on the complex and critical functions carried out by SMO and Spm in the physiology and pathology of mammalian brain. The production of $\mathrm{H}_{2} \mathrm{O}_{2}$ and $\mathrm{AP}$, derived from $\mathrm{Spm}$ oxidation, together with direct effects of Spm on AMPA and KA receptors, are synergistically involved in ROS increase and ultimately to neuronal degeneration and death. SMO enzyme can be considered one of the most important $\mathrm{H}_{2} \mathrm{O}_{2}$ producers in the brain and the transgenic JoSMOrec mice represent a useful genetic model for studying brain pathologies such as epilepsy, Alzheimer's disease and other forms of dementia [4].

\section{Acknowledgements}

The authors thank the University of Roma Tre for financial support.

\section{Authors' details}

"University of "Roma Tre", Rome, Italy. ${ }^{2}$ IRCCS Fondazione Santa Lucia, Rome, Italy. 'Istituto Nazionale per le Malattie Infettive, IRCCS "L. Spallanzani", Rome, Italy.

Published: 13 September 2013

\section{References}

1. Cervelli M, Amendola R, Polticelli F, Mariottini P: Spermine oxidase: ten years after. Amino Acids 2012, 42:441-450.

2. Williams K: Interactions of polyamines with ion channels. Biochem J 1997, 325:289-297.

3. Fleidervish IA, Libman L, Katz E, Gutnick MJ: Endogenous polyamines regulate cortical neuronal excitability by blocking voltage-gated $\mathrm{Na}+$ channels. Proc Natl Acad Sci USA 2008, 105:18994-18999. 
4. Cervelli M, Bellavia G, D'Amelio M, Cavallucci V, Moreno S, Berger J, Nardacci R, Marcoli M, Maura G, Piacentini M, Amendola R, Cecconi F, Mariottini P: A new transgenic mouse model for studying the neurotoxicity of spermine oxidase dosage in the response to excitotoxic injury. PLOS ONE 2013, 8:e64810.

\section{doi:10.1186/1750-1326-8-S1-P4}

Cite this article as: Angelucci et al.: A new transgenic mouse model for studying the neurotoxicity of spermine oxidase dosage in the response to excitotoxic injury. Molecular Neurodegeneration 2013 8(Suppl 1):P4.

Submit your next manuscript to BioMed Central and take full advantage of:

- Convenient online submission

- Thorough peer review

- No space constraints or color figure charges

- Immediate publication on acceptance

- Inclusion in PubMed, CAS, Scopus and Google Scholar

- Research which is freely available for redistribution

Submit your manuscript at www.biomedcentral.com/submit
C) Biomed Central 